УДК 353.2: 342.9

DOI: $10.34132 /$ pard2021.12.09

\title{
DEMOCRACY, TRANSPARENCY, AND PARTICIPATION THROUGH THE OPENNESS OF PUBLIC INFORMATION IN PEMALANG REGENCY, INDONESIA
}

Susniwati, M.Si., Lecturer at Sekolah Tinggi Ilmu Administrasi, Bandung, Indonesia.

Moh. Zamili, M.M.Pd., Lecturer at Universitas Ibrahimy Situbondo, Indonesia.

Neni Sriwahyuni, M.Si., Head of Department of Communication, Informatics, and Encoding, Aceh Tamiang District, Indonesia.

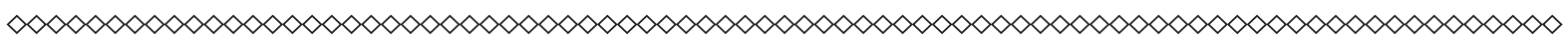

The openness of public information is an essential or inseparable part of democracy. The principles of democracy are participation, inclusion, representation, transparency, accountability, responsibility, free and fair competition, and solidarity. Transparency and participation are linked to the openness of information that allows people to get accurate and sufficient information. This research focuses on the dynamics of democracy in transparency and participation through the openness of public information in Pemalang Regency. The method that used in this research is the qualitative method, since the data is obtained from observation, interviews, and documentation. The result shows that information is restricted by the classification of public information, mechanism access, limitation of tools to deliver the information. Moreover, the database of information has not met the requirement for more up-to-date information. Also, the level of participation of the people in public information in Pemalang Regency is still low.

Key words: democracy, transparency, participation, openness, public information 
Introduction. The idea of a democratic country refers to the increasing of participation, transparency, and accountability in public service. The role of public administration plays a part in helping to empower people and to create democracy. In public administration theory, democracy and transparency are seen as a whole supporting unit in good governance complemented by public participation (Harrison \& Sayogo, 2014; Kosack \& Fung, 2014; McDermott, 2010). Thus, the principles of democracy which are participation, inclusion, representation, accountability, responsibility, free and fair competition, and solidarity, used as a primary institutional development and democratic process (Tjhin, 2005).

The openness of public information is an essential or inseperable part of democracy itself (Sakapurnama \& Safitri, 2012). Transparency and participation are linked to the openness of information that allows people to get accurate and sufficient information. Transparency is the availability of information about an organization or actor allowing external actors to monitor the internal workings or performance of that organization (Grimmelikhuijsen \& Porumbescu, 2013). Besides, the effective participation of public will increase transparency in development, accountability of the authority, which is in accord with the law to eventually creating good governance (Waheduzzaman, 2008).

Transparency and participation are essential parts of realizing good governance. The principles of good governance are accountability, transparency, formulation of open political policies, participation, the rule of law, and a sense of public justice for every public policy. (Sakapurnama \& Safitri, 2012). To create good governance starts with encouraging open government. There are five requirements of open government, (1) the right to monitor the behavior of public officials in fulfilling their roles, (2) the right to information, (3) the right to involve and participate in the process of public policy, (4) freedom of expression, (5) the right to object (Sakapurnama, Jannah, Muslim, \& Hariyati, 2012).

Indonesia recognizes the right to information in the 1945 Constitution (UUD 45) Article 28F, which states that everyone has the right to 
communicate and obtain information to develop their personal and social environment, as well as the right to seek, obtain, possess, store, process, convey information using any of the available channels. Information is a processed data that has meaningful and helpful form for the recipient in making current or future decisions. (Davis, 2013).

In realizing good governance, the Indonesian government passed law No. 14, 2008, on the openness of public information (called, KIP). The freedom of information and accountability are two interrelated governance principles (Piotrowski, 2007). However, the KIP law is expected to create transparent, participative, and accountable governance. "Good governance is a concept of organized government which clean, democratic, and effective (Tahir, 2014). Government transparency ensures a more efficient, democratic, trusted, and honest government (Hood, 2006).

The availability of KIP law affects corruption in Indonesia. According to Sakapurnama et al (2012) Internationally, the openness of information has been recognized as one of the pillars of eradication effort on corruption. Every year, the corruption index in Indonesia has been improving not significantly, as shown in the table below.

Table 1.

\section{Indonesia's Rank and Score in Corruption Perception Index 2012-2016}

\begin{tabular}{|c|c|c|c|c|}
\hline No & Year & Global Rank & Score & Info \\
\hline 1 & 2012 & 118 & 32 & \\
\hline 2 & 2013 & 114 & 32 & \\
\cline { 1 - 2 } 3 & 2014 & 107 & 34 & \multirow{2}{*}{ 176 Countries } \\
\hline 4 & 2015 & 88 & 36 & \\
\hline 5 & 2016 & 90 & 37 & \\
\hline
\end{tabular}

Source: Transparency International, 2017 
The table shows that Indonesia's rank has been decreased and increased one point. Indonesia is ranked below other ASEAN countries like Singapore, Brunei, and Malaysia. In 2017, Transparency International Indonesia (TII) institute surveyed on Corruption Perceptions Index (CPI) in twelve cities. The twelve cities were selected based on provincial capitals, contributors to the national gross domestic product (GDP), and represent the western, central, and eastern areas of Indonesia. The (CPI) 2017 on twelve cities shown in the graph below.

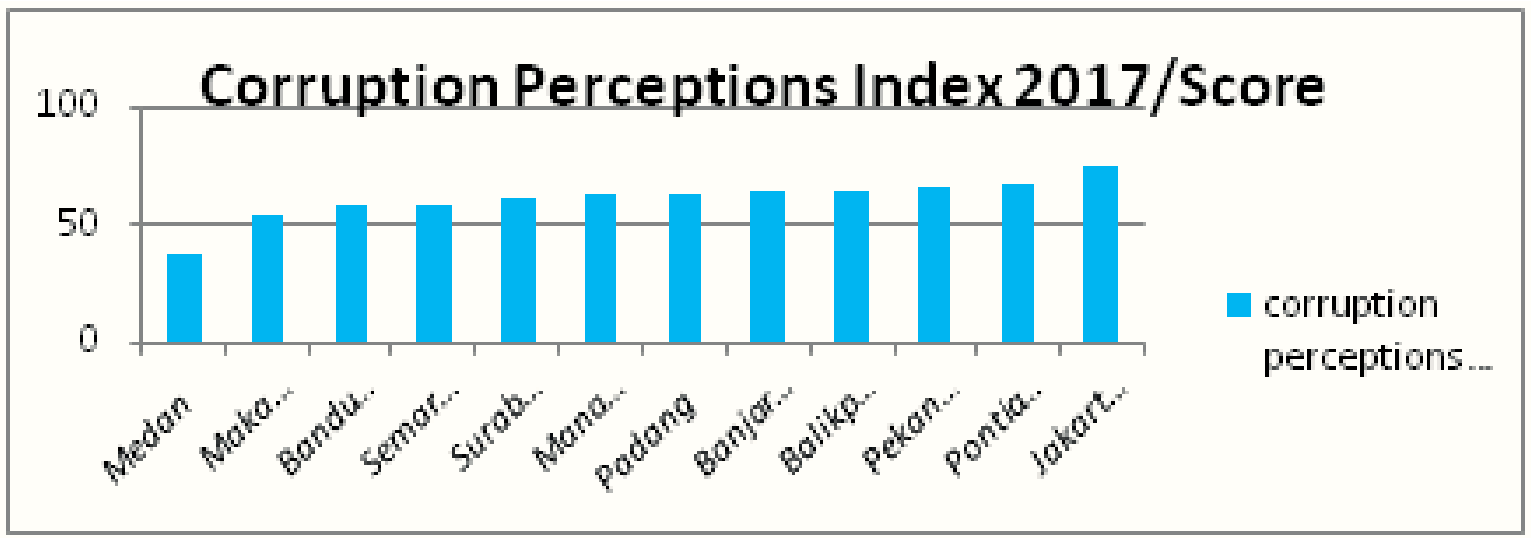

Graph 1. The Corruption Perceptions Index in Indonesia 2017

Source: Transparency International Indonesia, 2017

The Graph above shows that North Jakarta is the cleanest city from corruption by score at $(73,9)$ Pontianak $(66,5)$ Pekanbaru $(65,5)$ Balikpapan $(64,3)$ Banjarmasin $(63,7)$ Padang $(63,1)$ Manado $(62,8)$ Surabaya $(61,4)$ Semarang $(58,9)$ Bandung $(57,9)$ Makassar $(53,4)$ and Medan is the most corrupt city by score at $(37,4)$.

There are several main actors in the openness of public information; they are Public Institution, information petitioners, and information users. Therefore, to realize the openness of public information, Public Institution appoints Information and Documentation Management (PPID). According to law of KIP, PPID is responsible for the storage, documentation, provision, and information services of a Public Institution. PPID is also in the field of public information and competence in the information and documentation management field. 
The law of KIP requires a region to create Regional Regulations (Perda) on the openness of public information and appoints PPID. The data summary of total PPID Provinces, Regencies, and Cities in Indonesia is shown in the table below.

Table 2.

\section{The Total of PPID Provinces, Regencies and Cities}

\begin{tabular}{|c|c|c|c|c|c|c|}
\hline No & Institution & Total & PPID & $\begin{array}{c}\text { Percentage } \\
(\%)\end{array}$ & $\begin{array}{c}\text { Have not } \\
\text { submitted } \\
\text { SK \&SOP }\end{array}$ & $\begin{array}{c}\text { Percentage } \\
(\%)\end{array}$ \\
\hline 1 & Provinces & 34 & 34 & $100 \%$ & 0 & $0 \%$ \\
\hline 2 & Regencies & 416 & 313 & $75.24 \%$ & 103 & $24.76 \%$ \\
\hline 3 & Cities & 98 & 90 & $91.84 \%$ & 8 & $8.16 \%$ \\
\hline
\end{tabular}

Data: Ministry of Home Affairs, 2019

The table above shows that some regencies have not implemented KIP law by not having PPID. The total of PPID Provincial Government is $88,24 \%$ and $47,1 \%$ for Regencies and Cities in Indonesia.

One of the regions in Central Java that implemented the law of KIP is Pemalang Regency. The Government of Pemalang Regency issued Regional Regulations (Perda) Number 1, 2011 about Transparency and Public Participation in Regional Government Implementation. Perda Number 1, 2011, ensures the right of the people to understand the process of planning, implementing, evaluating, and observing the regional government implementation.

In addition, the regulation classifies public information into two; first, information should be public, and second, there are exempted information. Public information includes: (a) public information that must be provided and announced periodically, (b) public information that must be announced in any case, (c) public information that must be available at any time. This classification of public information is issued by the Government of Pemalang Regency to facilitate the people who wanted to know public information. 
Moreover, the regulation SOP also regulates the mechanism of public information services. PPID in Pemalang Regency have two mechanisms in implementing public information services; they are direct and indirect. It means providing information service desk and internet access service desk. The purpose of this research is to investigate the dynamics of democracy in transparency and participation through the openness of public information in Pemalang Regency.

Research Method. The methodology used in this research is qualitative research with underlie considerations due to its characteristics natural setting (Creswell \& Creswell, 2018). Qualitative researchers tend to collect field data in a location where participants experience issues or problems (Zamili, 2015, 2017). Researcher as a key instrument. Data collection technique through observation, interview, and documentation. The researcher observes the behavior and activities of individuals at the location. The researcher is also interviewing participants by phone or group interview with six or more groups. Documentation can be public such as, newspapers, articles, office reports, or private documents.

Literature Review. Transparency means government clarity, openness, accessibility, accountability, and responsibility to public society. The concept of transparency in public administration is considered in different ways. For instance, in jurisprudence, particularly in legal proceedings, transparency is considered as relations and information process (Praskova, 2005). According to Grimmelikhuijsen, Porumbescu \& Hong (2013), The concept of transparency has two aspects; first, public communication by the government and second, the right of people to information access. Meanwhile, the process of transparency includes standard procedure requirements, Consultation processes, and Appeal rights. Standard, not convoluted and transparent (Smith, 2004).

Haryatmoko (2011) stated that transparency is placed in participation because by opening access to information, civil society will give feedback and participate in implementing public policies. A clean, democratic and effective government implementation is a concept of good governance. Transparency in the implementation of regional government provides an 
opportunity for the public to know the policies that will and have taken (Tahir, 2014).

Transparency will encourage escalation in public accountability. Meanwhile, accountability will hard to accomplish without public monitoring in making a decision (Mardiyanta, 2013). There is a close link between unaccomplished public participation without transparency. According to Waheduzzaman (2008), "the effective participation of public will increase transparency in development, accountability of the authority, which is in accord with the law to eventually creating good governance.

Transparency is one of the foundations of good governance. Transparency refers to the extent in which external stakeholders have access to information about how public organizations work (Meijer, 2013). According to Oliver (2004:5) government transparency focus on four key aspects (1) Clarity of roles and responsibilities (2) Public availability of information (3) Open budget preparation, execution, and reporting (4) Assurances of integrity.

Information transparency is the level of information availability and accessibility in which public can participate in every government activity" (Zhu, 2004). The concept is to imply that the information quality and quantity accessed by the public is important. This concept is important because many public organizations have certain quality information, but it is hard to access. Thus, information transparency refers not only to the availability but also to the easiness of public access. The easiness of public access is also important because if the information is not properly structured, organized, and presented, it will be difficult for the public to use the information (Galitz, 2007).

Information is the lifeblood of an increasingly transparent world. Oliver (2004:31) to be a truly transparent organization, four key elements are required:

1. A culture dedicated to openness and a commitment to transparency from an organization's most senior leadership

2. Programs and processes that encourage and ensure openness at every level, that reward transparency and mete out quick and decisive punishment for opacity, obfuscation, and fraud 
3. Well-trained workers, managers, and administrators at all levels of the organization with the wisdom, integrity, confidence, and security to do and say what is right and to recognize and act when the organization or individuals are not doing things that should be done

4. Established means of proactive communication to the organization's important stakeholders.

The law of KIP defines information as statements, ideas, and signs that contain values, meanings, and messages. Whereas Dipopramono (2017) states that Generated, stored, managed, sent, and received information by a public institution in accord with the law, as well as other information related to the public interest. The openness of the public information will provide access to the public so that they can involve. Access is the ability to get benefit from something (Ribot \& Peluso, 2009).

There is a close link between transparency, accountability, and participation. Public participation will not accomplish without transparency. Transparency will also escalate public accountability. Meanwhile, accountability will hard to accomplish without public monitoring in making a decision (Mardiyanta, 2013). According to Krina \& Loina (2003), there are five forms of participation; (1) the involvement of officials through the creation of value and commitment (2) the existence of a forum to accommodate participation (3) the involvement of the public in making a decision (4) the focus of government by providing direction and inviting others to participate in a meeting forum with public communities (5) access for the public to express opinions in the process of making a decision.

The terms of public participation, citizen participation, political participation, and civic engagement are often used interchangeably by experts in public administration, although each term reflects a slightly different meaning from one and another. The terms public participation, citizen participation, political participation, and civic engagement are often used interchangeably, yet they each reflect different aspects of participation. Public participation is the broadest concept, and it includes participation activities that involve the public, the media, and other nongovernment social groups (Callahan K, 2007; Yang K \& Callahan K, 2005). Citizen participation Refers to the role of the public in the process 
of administrative decision making or involvement in making service delivery and management decisions.

Result and Discussion. The purpose of the law of KIP stated in Article 3, (a) ensure the right of citizens to know about plans, programs, and public decision-making processes, as well as the reasons (b) encourage public participation in the public policy-making process (c) increase the active public role in making public policies and organize good public institution (d) implement a good, transparent, effective, efficient, accountable and responsible government (e) know the reasons of public policies that affect lives of many people (f) develop knowledge and intellectual life of the nation $(\mathrm{g})$ improve management and services of information in public institution environment to produce qualified information services (KIP law, 2008).

From the explanation above, the law of KIP encourages transparency and public participation in every government policy. According to Kim \& Lee (2012), "government provides more opportunities for society and encourages inputs on evaluating government performance and decisionmaking policy." Abe (2005) states that direct public participation will have an essential impact such as spared of manipulation and clarifying what the society wants. Also, give value to planning formulation legitimacy because many parties are involved and increase public awareness and political skills. Direct participation data through Information and Documentation Management Officer (called PPID) information desk is shown in the graph below.

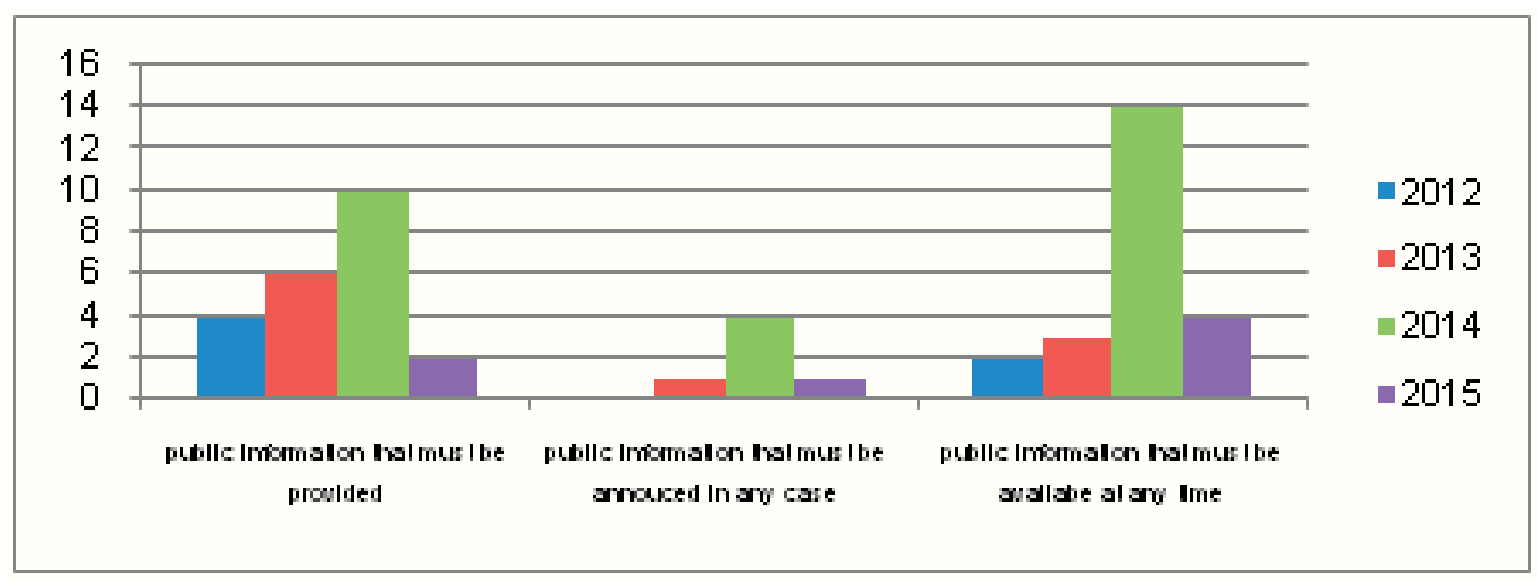

Graph 3.Direct Public Participation in Pemalang 2012-2015

Source: Ministry of Communication and Informatics Pemalang Regency, 2018 
Meanwhile, the implementation of indirect public information services is through electronic and non-electronic media. Society can access public information through the Pemalang PPID official website at http://ppid.pemalangkab.go.id. in order to see public information on the relevant of regional apparatus organization (called, OPD). However, there are some OPD in Pemalang Regency that does not have an official website. The table below shows the data of the official OPD website in Pemalang Regency.

Table 4.

The list of official website in Pemalang Regency

\begin{tabular}{|l|l|l|}
\hline No & \multicolumn{1}{|c|}{ OPD } & \multicolumn{1}{c|}{ Website Address } \\
\hline 1. & General Section & http://umum.pemalangkab.go.id \\
\hline 2. & $\begin{array}{l}\text { Public Service } \\
\text { Section, RB }\end{array}$ & http://pprb.pemalangkab.go.id \\
\hline 3. & $\begin{array}{l}\text { Public Welfare } \\
\text { Section }\end{array}$ & http://kesra.pemalangkab.go.id \\
\hline 4. & Organization Section & http://organisasi.pemalangkab.go.id \\
\hline 5. & Construction Section & http://adpem.pemalangkab.go.id \\
\hline 6. & $\begin{array}{l}\text { Economy and Natura } \\
\text { Resources }\end{array}$ & http://perekonomiandansda.pemalangkab.go.id \\
\hline 7. & Governance Section & http://tapem.pemalangkab.go.id \\
\hline 8. & Law Section & http://hukum.pemalangkab.go.id \\
\hline 9. & Kesbangpolinmas & http://kesbangpolinmas.pemalangkab.go.id \\
\hline 10. & $\begin{array}{l}\text { DPRD Pemalang } \\
\text { Regency }\end{array}$ & http://dprd-pemalangkab.go.id \\
\hline 11. & Inspectorate & http://inspektorat.pemalangkab.go.id \\
\hline 12. & Dindikbud & http://dindikbud.pemalangkab.go.id \\
\hline 13. & Dispermades & http://dinpermasdes.pemalangkab.go.id \\
\hline
\end{tabular}


Democracy, transparency, and participation through the openness of public information in pemalang regency, Indonesia

continutation of the table 4

\begin{tabular}{|l|l|l|}
\hline 14. & Environment & http://dlh.pemalangkab.go.id \\
\hline 15. & $\begin{array}{l}\text { Public Works and } \\
\text { Housing }\end{array}$ & http://dputr.pemalangkab.go.id \\
\hline 16. & Diskominfo & http://diskominfo.pemalangkab.go.id \\
\hline 17. & Libraries and Archives & http://dinpusarda.pemalangkab.go.id \\
\hline 18. & Fisheries & http://disperik.pemalangkab.go.id \\
\hline 19. & Transportation & http://dishub.pemalangkab.go.id \\
\hline 20. & Manpower & http://disnaker.pemalangkab.go.id \\
\hline 21. & Diskoperindag & http://diskoperindag.pemalangkab.go.id \\
\hline 22. & $\begin{array}{l}\text { Public Housing and } \\
\text { Residential }\end{array}$ & http://disperkim.pemalangkab.go.id \\
\hline 23. & PMPTSP & http://dinaspmptsp.pemalangkab.go.id \\
\hline 24. & KBPP PA & http://dinsoskbpp.pemalangkab.go.id \\
\hline 25. & Dispora & http://disparpora.pemalangkab.go.id \\
\hline 26. & Disdukcapil & http://disdukcatpil.pemalangkab.go.id \\
\hline 27. & Agriculture & http://dispertan.pemalangkab.go.id \\
\hline 28. & Health Service & http://dinkes.pemalangkab.go.id (non-akses) \\
\hline 29. & BPBD & http://bpbd.pemalangkab.go.id \\
\hline 30. & RSUD Dr. Azhari & \\
\hline 31. & Satpol PP & http://satpolpp.pemalangkab.go.id \\
\hline 32. & BKD & http://bkd.pemalangkab.go.id \\
\hline 33. & $\begin{array}{l}\text { Management of } \\
\text { Regional Revenue }\end{array}$ & http://bapenda.pemalangkab.go.id \\
\hline 34. & BPKAD & http://bpkad.pemalangkab.go.id \\
\hline 35. & BAPPEDA & http://bappeda.pemalangkab.go.id \\
\hline
\end{tabular}


continutation of the table 4

\begin{tabular}{|l|l|l|}
\hline 36. & Ampelgading District & http://ampelgading.pemalangkab.go.id \\
\hline 37. & Bantarbolang District & http://bantarbolang.pemalangkab.go.id \\
\hline 38. & Belik District & http://belik.pemalangkab.go.id \\
\hline 39. & Bodeh District & http://bodeh.pemalangkab.go.id \\
\hline 40. & Comal District & http://comal.pemalangkab.go.id \\
\hline 41. & Moga District & http://moga.pemalangkab.go.id \\
\hline 42. & Pemalang District & http://pemalang.pemalangkab.go.id \\
\hline 43. & Petarukan District & http://petarukan.pemalangkab.go.id \\
\hline 44. & Pulosari District & http://pulosari.pemalangkab.go.id \\
\hline 45. & Randudongkal District & http://randudongkal.pemalangkab.go.id \\
\hline 46. & Taman District & http://taman.pemalangkab.go.id \\
\hline 47. & Ulujami District & http://ulujami.pemalangkab.go.id \\
\hline 48. & Warungpring District & http://warungpring.pemalangkab.go.id \\
\hline 49. & Watukumpul District & http://watukumpul.pemalangkab.go.id \\
\hline
\end{tabular}

Source: Diskominfo Pemalang Regency (cultivated by author, 2020)

The table above shows that almost all OPDs and Districts in Pemalang Regency have an official website. However, Health Service and Dr. Azhari Regional Public Hospital (called, RSUD) are both OPD that have not have a website. "The minimum supporting indicator of an institution is appropriately transparent if the regulation ensures the right to information, information center, website, public service advertisement, printing, and announcement" (Solihin, 2006).

The result of observation indicates that many public agency websites are not up-to-date. So that, the availability of public information is not working properly. The chart below shows the data of website reports in Pemalang Regency. 
Website Condition

in Pemalang Regency
Previously

Active

$10 \%$
Previously

Active but

Rarely Update

$3 \%$

No Update

$87 \%$

\# Previously Active

E Previously Active but Rarely Update

mo Update

Chart 1.The report of website condition in Pemalang Regency Source: Diskominfo Pemalang Regency (2019)

The chart shows that there is $87 \%$ of the website have not been updated and others are previously active but rarely updated. In the management public information transparency requires a commitment to improving regional website-managing in Pemalang Regency.

PPID officers have to prepare public information by reporting the related OPD information. PPID performance is assessed annually by the Central Java KIP with specified criteria. One of them is the assessment in Pemalang Regency website in terms of financial statements delivery. The chart below shows financial statement in Pemalang Regency, 2017.

The chart shows the financial statement delivery in Pemalang Regency with the percentage of closed statement by $60 \%$ and open statement by $40 \%$. Financial statement delivery is one of public information that must be provided periodically by the public agency. In addition, KIP issues an annual report of PPID rank for Regencies and Cities in Central Java.

The report focuses to evaluate, assess, and set the openness of public information on Public Agency that refers to the standard public information services. This activity is expected to map the idea of the openness of public information and evaluation, activity, performance, 
and budget. The rank result of the openness of public information on Public Agency through PPID performance is shown in the table below.

\section{Financial Statement 2017}

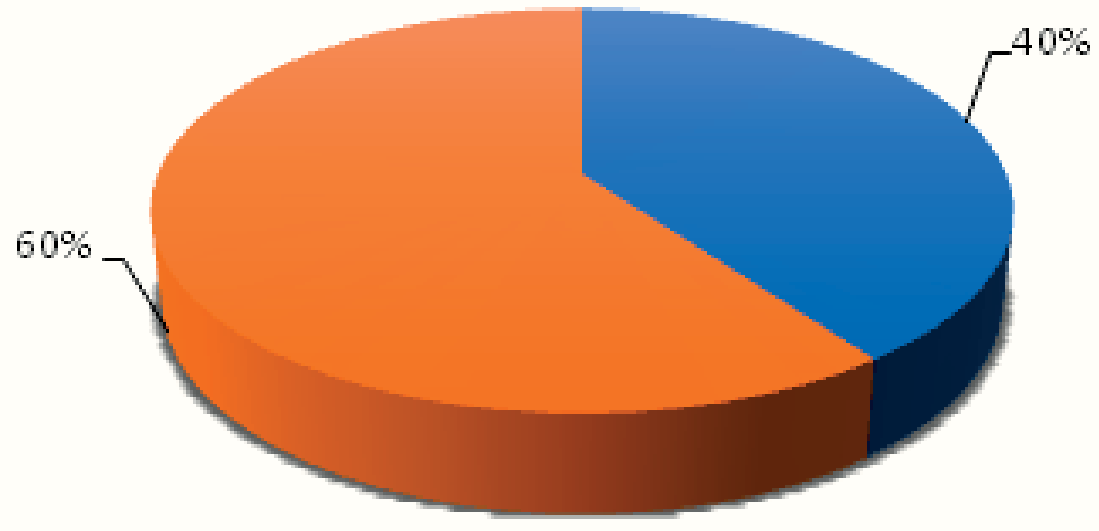

Open

Closed

Chart 2. Financial Statement Transparency in Pemalang Regency Source: Central Java Information Commission (2018)

Table 5 .

\section{PPID Rank in Pemalang Regency 2013-20170}

\begin{tabular}{|c|c|c|}
\hline Year & Rank & Info \\
\hline 2013 & 11 & \\
\hline 2014 & - & \\
\hline 2015 & - & \multirow{2}{*}{ 35 Regencies/Cities } \\
\hline 2016 & - & \\
\hline 2017 & - & \\
\hline 2018 & 13 & \\
\hline
\end{tabular}

Source: Central Java Information Commission (2018)

The table shows that PPID in Pemalang Regency has not been able to improve its rank since 2014. The steps of information evaluation and assessment by Central Java Information Commission consist of (1) evaluation and assessment is done through visitation to 35 Regencies and 
Cities in Central Java (2) Public Agency allowed to assess governance public information through self-assessment questionnaire provided by Central Java Information Commission (3) Visitation of SAQ verification and presentation (4) Public Agency is allowed to deliver governance public information before Assessment Team.

Conclusion.The research focuses on the dynamics of democracy in transparency and participation through the openness of public information in Pemalang Regency shows that democratic information is restricted by the classification of public information, mechanism access, limitation of tools to deliver the information. Moreover, the database of information has not met the requirement for more up-to-date information. Also, the level of participation of the people in public information in Pemalang Regency is still low.

\section{Received: 12.02.21}

\section{ДЕМОКРАТІЯ, ПРОЗОРІСТІ І УЧАСТІ ЧЕРЕЗ ВІДКРИТІСТЬ СУСПІЛЬНОЇ ІНФОРМАЦІЇ В РЕГІОНІ PEMALANG (IНДOНЕЗІЯ)}

Susniwati, M.Si., Lecturer at Sekolah Tinggi Ilmu Administrasi, Bandung, Indonesia.

Moh. Zamili, M.M.Pd., Lecturer at Universitas Ibrahimy Situbondo, Indonesia.

Neni Sriwahyuni, M.Si., Head of Department of Communication, Informatics, and Encoding, Aceh Tamiang District, Indonesia.

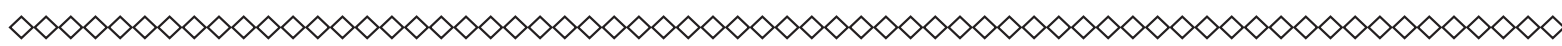

У статті показано щуо відкритість суспільної інформації $\epsilon$ надважливою або навіть невідчємною частиною демократії. Принциипи демократії - ие участь, інклюзивність, представництво, прозорість, однозначність, відповідальність, вільна та справедлива конкуренція та солідарність. Прозорість та участь пов'язані з відкритою інформачією, щзо дозволяє людям отримувати точну та достовірну інформачію. Дослідження фокусується на динаміці 
демократії у прозорості та участі через відкриття публічної інформації в регіоні Pemalang. Методика, використана у изьому дослідженні, є емпіричною, оскільки дані, отримані в результаті спостереження, інтервґю та документування. Результати щзо були отримані показують інформачія обмежена класифікацією загальнодоступної інформації, механізмом доступу, обмеженням інструментів які сприяють отриманню інформації. Більше того, інформаційна база даних не відповідає сучасним вимогам та потребам до більш актуальної інформачії. Також,показано щзо рівень участі людей у прочесі отримання та використання суспільної інформації в регіоні Pemalang натепер залишається дуже низьким.

Ключові слова: демократія, прозорість, участь, відкритість, публічна інформачія.

\section{References}

1. Abe, A. (2005). Perencanaan Daerah Partisipatif. Yogyakarta: Pembaruan. [in Indonesian].

2. Callahan K. (2007). Elements of Effective Governance: Measurement, Accountability and Participation. Boca Raton: CRC Press.

3. Creswell, J. W., \& Creswell, J. D. (2018). Research Design: Qualitative, Quantitative, and Mixed Methods Approaches (5th ed.). London: Sage.

4. Davis, G. B. (2013). The Blackwell Encyclopedia of Management Information Systems. In Journal of Chemical Information and Modeling (Vol. 53). https://doi.org/10.1017/CBO9781107415324.004

5. Dipopramono, A. (2017). Keterbukaan Dan Sengketa Informasi Publik. Jakarta: Renebook. [in Indonesian].

6. Galitz, W. O. (2007). The Essential Guide to User Interface Design: An Introduction to GUI Design Principles and Techniques ( $3^{\text {r }}$ ed.). New York: John Wiley and Sons.

7. Grimmelikhuijsen S, Porumbescu G, H. B. (2013). The effect of transparency on trust in government: A cross-national comparative experiment. Public Administration Review, 73(4), 575-586. 
8. Grimmelikhuijsen, S., Porumbescu, G., Hong, B., \& Im, T. (2013). The Effect of Transparency on Trust in Government. Public Administration Review, 73(4), 575-586.

9. Harrison, T. M., \& Sayogo, D. S. (2014). Transparency, participation, and accountability practices in open government: A comparative study. Government Information Quarterly, 31(4), 513-525. https://doi.org/10.1016/j.giq.2014.08.002

10. Haryatmoko. (2011). Etika Publik untuk Integritas Pejabat Publik dan Politisi. Jakarta: PT. Gramedia Pustaka Utama. [in Indonesian].

11. Hood, C. (2006). "Transparency in Historical Perspective", in C. Hood and D.Heald (eds), Transparency: The Key to Better Governance? Proceding of the British Academy 135. Oxford:, 3-24. Oxford University Press.

12. Kim, S., \& Lee, J. (2012). E-Participation, Transparency, and Trust in Local Government. Public Adminisitration Review, 72, 819-828. https://doi. org/10.111/j.1540-6210.2012.02593.x.E-Participation

13. Kosack, S., \& Fung, A. (2014). Does Transparency Improve Governance? Annual Review of Political Science, 17(1), 65-87. https://doi. org/10.1146/annurev-polisci-032210-144356

14. Krina, P., \& Loina, L. (2003). Indikator \& Alat Ukur Prinsip Akuntabilitas, Transparansi \& Partisipasi. Jakarta.

15. Mardiyanta, A. (2013). State of the art: Konsep partisipasi dalam ilmu administrasi publik State of the art: Participation concept in public administration. Masyarakat, Kebudayaan Dan Politik, Vol. 26, N, 227-242. [in Indonesian]

16. McDermott, P. (2010). Building open government. Government Information Quarterly, 27(4), 401-413. https://doi.org/10.1016/j.giq.2010.07.002

17. Meijer, A. (2013). Understanding the Complex Dynamics of Transparency. 73, 429-439. https://doi.org/10.1111/puar.12032.Understanding

18. Oliver, R.W. (2004). What is Transparency? https://doi.org/0071457224

19. Piotrowski, S. J. (2007). Governmental Transparency in the Path of Administrative Reform. New York: State University of New York Press Albany.

20. Praskova, S. V. (2005). Theoretical Foundations of Publicity of the Justice. Cand. Jurid. Sciences Dissertation, Russian Academy of Justice, Moscow, 214

21. Republik Indonesia. Undang-Undang Nomor 14 Tahun 2008 tentang Keterbukaan Informasi Publik. [in Indonesian].

22. Ribot, J. C., \& Peluso, N. L. (2009). A Theory of Access. Rural Sociology, 68(2), 153-181. https://doi.org/10.1111/j.1549-0831.2003.tb00133.x 
23. Sakapurnama, E., Jannah, L. M., Muslim, M. A., \& Hariyati, D. (2012). Membuka Informasi, Menuju Good Governance, Sebuah Telaah Implementasi UU Keterbukaan Informasi Publik di Kota Surakarta dan Kabupaten Lombok Barat. Jakarta: Penerbit Universitas Indonesia. [in Indonesian].

24. Sakapurnama, E., \& Safitri, N. (2012). Good governance aspect in implementation of the transparency of public information law. Bisnis \& Birokrasi, Jurnal Ilmu Administrasi Dan Organisasi, 19(1), 69-78.

25. Smith, R. D. (2004). Regulatory transparency in OECD countries: Overview, trends and challenges. Australian Journal of Public Administration, 63(1), 66-73. https://doi.org/10.1111/j.1467-8500.2004.00360.x

26. Solihin, D. (2006). Mewujudkan Keuangan Negara yang Transparan, Partisipatif, dan Akuntabel, Transparansi dalam Diklatpim Tingkat IV Angkatan III Pusdiklat Pegawai BPK. Jakarta. [in Indonesian].

27. Tahir, A. (2014). Kebijakan Publik \& Transparansi Penyelenggaraan Pemerintah Daerah. Bandung: Alfabeta. [in Indonesian]

28. Tjhin, C. S. (2005). Post Tsunami Reconstruction and Peace Building in Aceh : Political Impacts and Potential Risks. 1-17.

29. Waheduzzaman. (2008). Good Governance In Democratic Developing Countries: A Paradox Journal School of Management. Victoria University. Melbourne.Australia., Page1-8.

30. Yang K \& Callahan K. (2005). Citizen involvement efforts and bureaucratic responsiveness: participatory values, stakeholder pressures, and administrative practicality. Public Administration Review, 2(67), 49-264.

31. Zamili, M. (2015). Menghindar dari Bias: Praktik Triangulasi dan Kesahihan Riset Kualitatif. LISAN AL-HAL: Jurnal Pengembangan Pemikiran Dan Kebudayaan, 9(2), 283-304. https://doi.org/10.35316/lisanalhal.v9i2.97 [in Indonesian].

32. Zamili, M. (2017). Riset Kualitatif dalam Pendidikan: Teori dan Praktik (1st ed.). Jakarta: RajaGrafindo Persada. [in Indonesian].

33. Zhu, K. (2004). Information Transparency of Busines- to- Business Electronic Markets: A Game Theoretic Analysis Management Science. 50(5), 670-685.

34. 


\section{Information about the Authors}

Susniwati: $\mathrm{PhD}$ in Public Administration, is an lecturer at Sekolah Sekolah Tinggi Ilmu Administrasi, Bandung, Indonesia.

ORCID.ORG/ 0000-0003-2933-6037

E-mail: susniwati@yahoo.com.

Moh. Zamili:PhD in Public Administration, is an lecturer at Universitas Ibrahimy, Jawa Timur, Indonesia.

ORCID.ORG/ 0000-0002-6987-8220

\section{E-mail: fine.zam@gmail.com}

Neni Sriwahyuni: $\mathrm{PhD}$ in Public Administration, is a head of Department of Communication, Informatics, and Encoding, Aceh Tamiang District, Indonesia.

\section{E-mail: yuniolatief13@gmail.com}

